\title{
Dynamic testing of High Energy Absorption (HEA) Mesh
}

\author{
Y. Potvin Australian Centre for Geomechanics, The University of Western Australia, Australia \\ D. Heal School of Civil and Resource Engineering, The University of Western Australia, Australia
}

\begin{abstract}
The HEA Mesh is a new surface support product currently under market development in Australia. It has been specifically designed to absorb energy from dynamic loading induced by large seismic events, but it is also suitable for application in very poor ground conditions where high convergence and squeezing ground are experienced. The HEA Mesh is an adaptation of the South African cable lacing technique which allows for the mechanised installation of pre-fabricated sheets of weld-mesh overlaid with a cable tendon pattern.

Recently, a dynamic loading test was organised in a Western Australian underground mine to quantify the energy absorption capacity of the HEA Mesh under dynamic loading conditions. The results from these tests are also compared with results obtained from other surface support that has undergone a similar testing procedure. The procedure is known as the simulated rockburst technique. In simulated rockbursts, dynamic loads are generated using controlled blasts designed to deliver strong ground motion at the wall of a drive, whilst minimising the effect of the gas expansion. Although it is recognised that the dynamic loading characteristics from blasting differs from the dynamic loading of a far field seismic event, it has the significant advantage of testing the entire support system (reinforcement and surface support), and its interaction with the deforming rock mass under real conditions.
\end{abstract}

\section{Introduction}

The Australian Centre for Geomechanics (ACG) has been conducting a number of simulated rockburst experiments in Western Australian underground mines as part of the Mine Seismicity and Rockburst Risk Management Project (Heal and Potvin, 2007). By simulating rockburst damage using blasting, it is possible to quantify the performance of complete ground support systems (incorporating reinforcing, retaining and holding elements as well as connections between the three) in situ when subjected to strong ground motion, as would be generated by a large seismic event nearby. Testing ground support systems in situ also allows accounting for issues such as the influence of: rock mass discontinuities, pre-existing rock mass damage, and the static stress field on rockburst damage, while investigating the performance of support and reinforcement systems.

Simulated rockburst experiments are conducted by blasting adjacent to the walls of disused excavations. Three blastholes are drilled parallel to the test wall at each site, as shown in Figure 1.
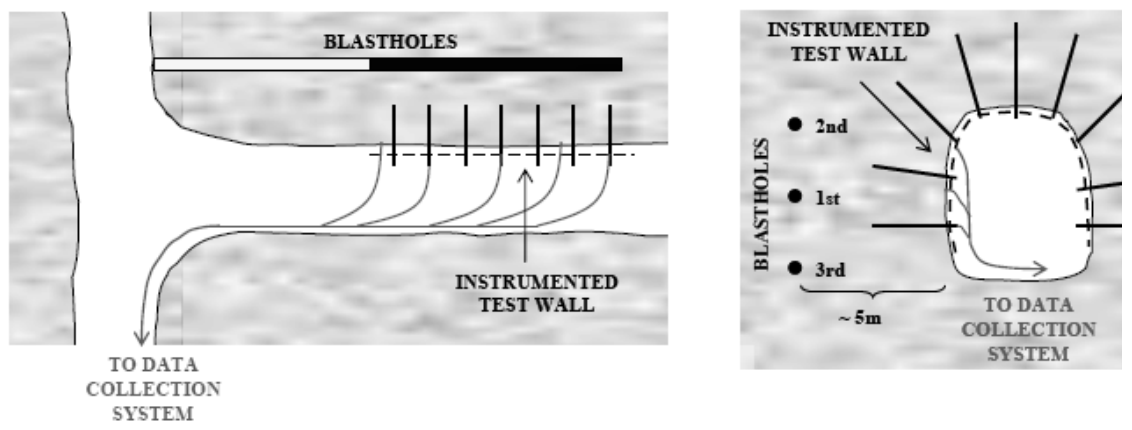

Figure 1 Conceptual plan and cross-sectional views of a simulated rockburst test site layout

Each blasthole is separately charged and detonated to allow successively larger dynamic loading upon the test wall. The blasts are designed to reproduce an actual seismic event as closely as possible. This can be 
achieved by maximising the release of shock wave energy and minimising the effects of rapidly expanding gases. As such, packaged emulsion products are considered most suitable for the experiments.

This paper is concerned with the dynamic testing of a new type of surface support called the HEA Mesh. A direct comparison of the HEA Mesh performance is made with a commonly used surface support; $70 \mathrm{~mm}$ layer of fibre-reinforced shotcrete (FRS) overlaid with weld-mesh, by testing the two systems side by side.

\section{HEA Mesh}

There is ample empirical evidence of the superior performance of the steel rope lacing technique commonly employed in the deep South African Gold mines in mitigating the consequences of large seismic events. The high performance of rope lacing has also been demonstrated through laboratory drop tests by Ortlepp and Stacey (1997). Because the technique is labour intensive, it has not been implemented in those countries using mechanised mining techniques.

During the last few years, the Australian Centre for Geomechanics has been working on the development of a mechanised rope lacing technique (Potvin, 2009; Potvin and Giles, 2008). The concept is simple and involves the pre-fabrication of a cable lacing pattern over a commonly used $2.4 \times 3 \mathrm{~m}$ sheet of weld-mesh (5.6 $\mathrm{mm}$ wire and $100 \times 100 \mathrm{~mm}$ aperture, Figure 2). The cable used in the prototype HEA Mesh is a $12.7 \mathrm{~mm}$ cable bolt clamped to the periphery and at different points to the sheet of weld mesh. The installation of HEA Mesh, which can be done mechanically using a jumbo, remains as easy, rapid and efficient as installing a regular sheet of weld mesh, making rope lacing techniques accessible to countries using mechanised mining.

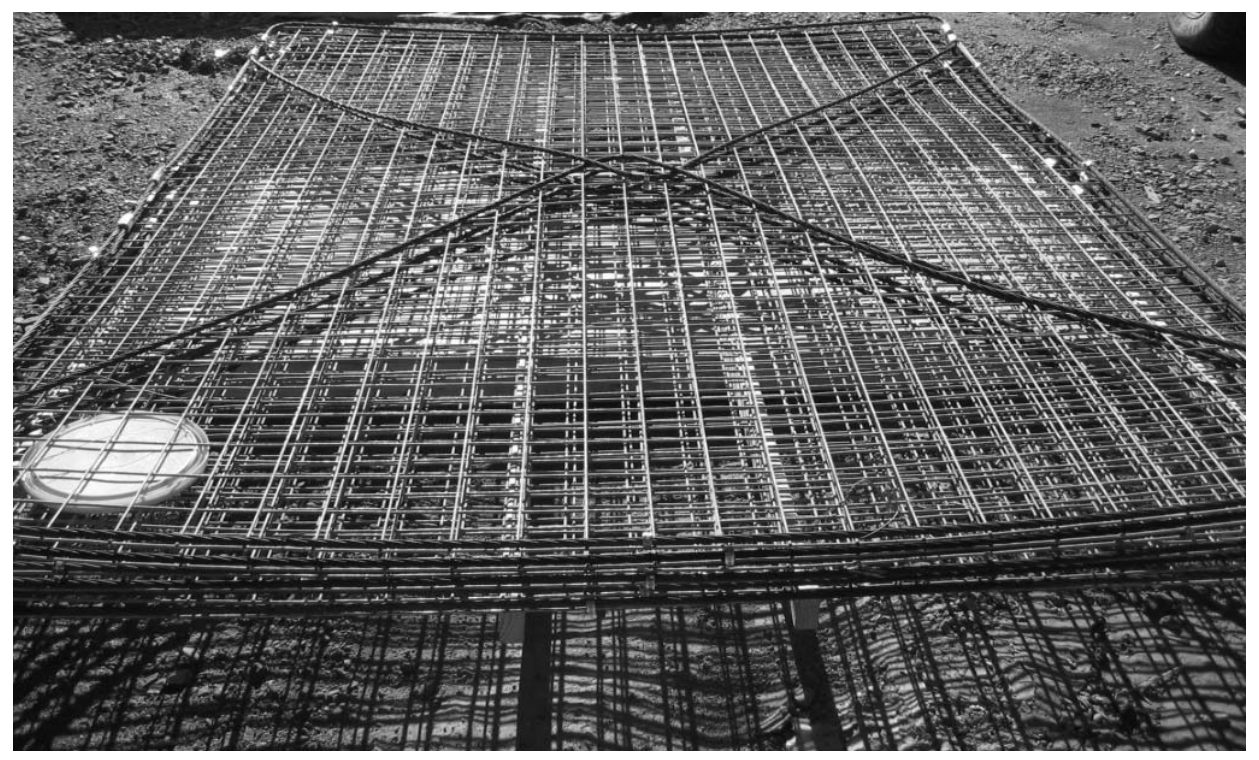

\section{Figure 2 Prototype of the HEA Mesh}

The 18 ton tensile strength cable bolt significantly increases the load bearing capacity of the mesh. Based on static laboratory tests, the HEA Mesh can sustain loads of well over 15 tons compared to the 2-4 tons of regular weld mesh. These tests involve central loading (pulling) of a full sheet of mesh, and the deflection is measured perpendicular to the plane of the sheet. More details on these tests are given in Potvin and Giles (2008). Also, with the cable being free to stretch over its entire length, the HEA Mesh has a good capacity to deform, which is not the case for FRS. The combined high load bearing and large deformation capacity produces a high energy absorption system.

One further advantage of the HEA Mesh is the excellent capability to transfer the load from the cable to the individual reinforcement elements. This is achieved because the cable is effectively laced over the deforming rock surface and wraps around rock bolts under the plate. Also, since the load capacity of the HEA Mesh is a good match to most reinforcement, the surface support is no longer the obvious 'weak link' of the support system. Another common 'weak link' of most mesh systems is the area of mesh overlap. The overlapping of 
HEA Mesh results in having two criss-crossing cables parallel to the mesh overlaps (Figure 3), transforming this weak area in regular meshing into a particularly strong area for the HEA Mesh.

The following sections will describe in detail the in situ dynamic testing procedure based on controlled blasting and the results from the comparative test of HEA Mesh versus FRS and mesh.

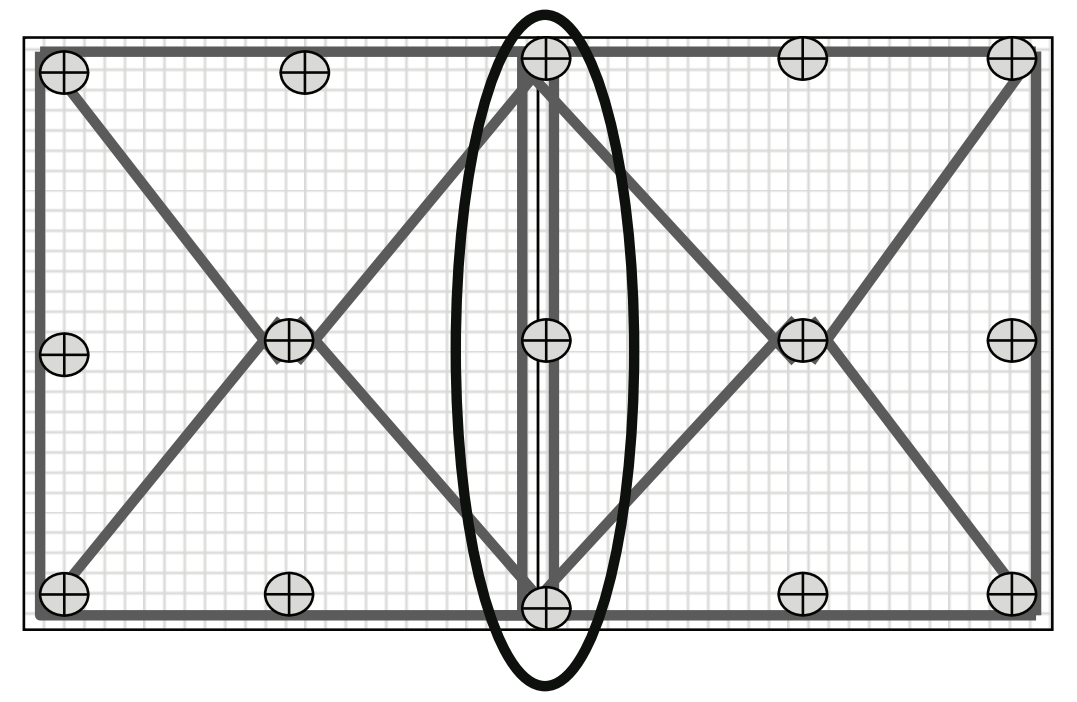

Figure 3 Two sheets of HEA Mesh overlapping. The overlap has two lengths of cable criss-crossing. The cable wraps around the rockbolt underneath the plate producing a good load transfer between the surface support and the reinforcement

\section{Test site layout}

Testing was undertaken in May 2008 at the Long Shaft Mine near Kambalda, Western Australia, approximately $690 \mathrm{~m}$ below surface. The ground support systems tested were:

\subsection{Support System 1 - cone bolts and HEA Mesh}

- $2.4 \mathrm{~m}$ long grouted cone bolts (bolt spacing $=1.2 \times 1.5 \mathrm{~m}$ ), installed with ROCKYIELD grout.

- HEA Mesh, $3 \times 2.5 \mathrm{~m}$ sheets (5.6 mm mesh gauge with high tensile cable lacing).

Although specifically designed for mechanised installation, the HEA Mesh for this experiment was installed manually, due to the non-availability of a jumbo drill. As a result, the quality of installation was somewhat compromised and in some areas, the lacing was not tight around the cone bolts and a good overlap was not achieved everywhere.

\subsection{Support System 2 - cone bolts and mesh with fibrecrete}

- $2.4 \mathrm{~m}$ long grouted cone bolts (bolt spacing $=1.2 \times 1.5 \mathrm{~m}$ ), installed with ROCKYIELD grout.

- Galvanised mesh, $3 \times 2.4 \mathrm{~m}$ sheets, $5.6 \mathrm{~mm}$ gauge.

- $70 \mathrm{~mm}$ thick fibrecrete (Synmix synthetic fibres).

The test site layout is shown in Figure 4, with a photograph of the test wall after set-up shown in Figure 5. The ground support layout instruction is shown in Figure 6 and the test wall drilling layout is shown in Figure 7. Sixteen $46 \mathrm{~mm}$ observation holes were drilled at 1 and $3 \mathrm{~m}$ height across the test wall. The main function of these holes is to determine the thickness of the damaged zone around the excavation, using observations from a borehole camera, before and after each simulated rockburst blast. These observation holes may also assist in venting the gases from the blasts. 


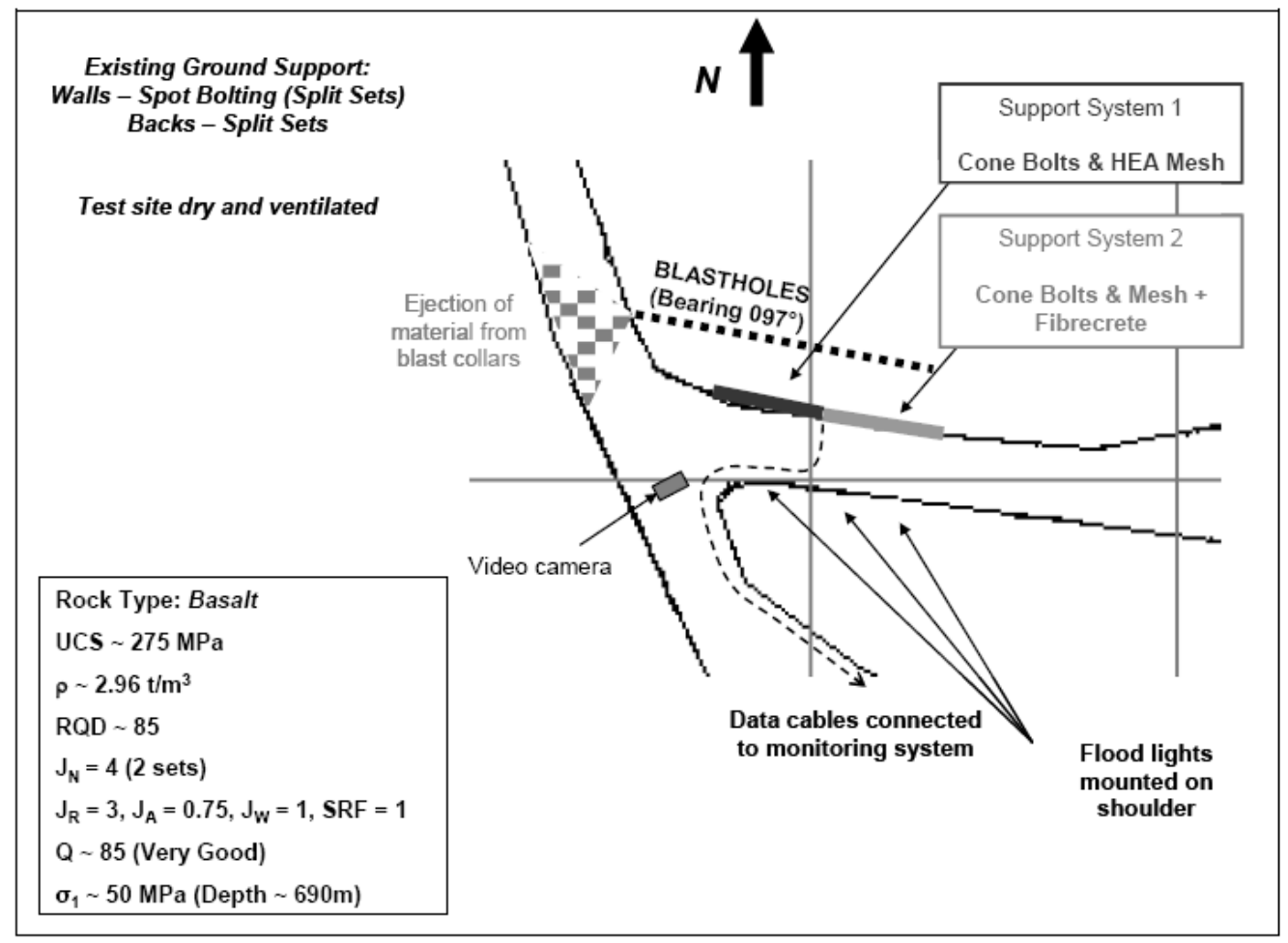

Figure 4 Long Shaft 14L Eimrock Access 1 test site layout

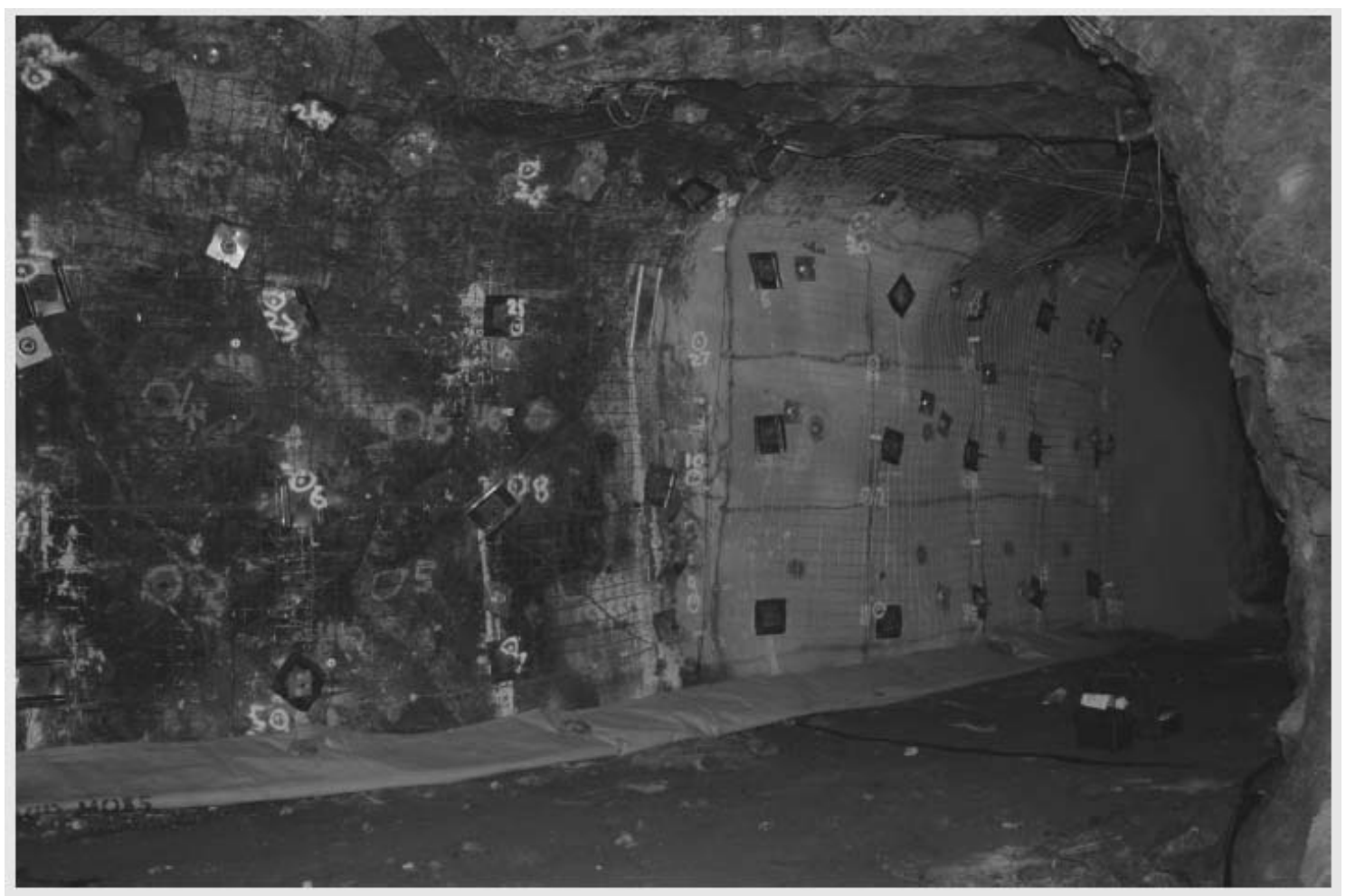

Figure 5 Photograph of the test wall 


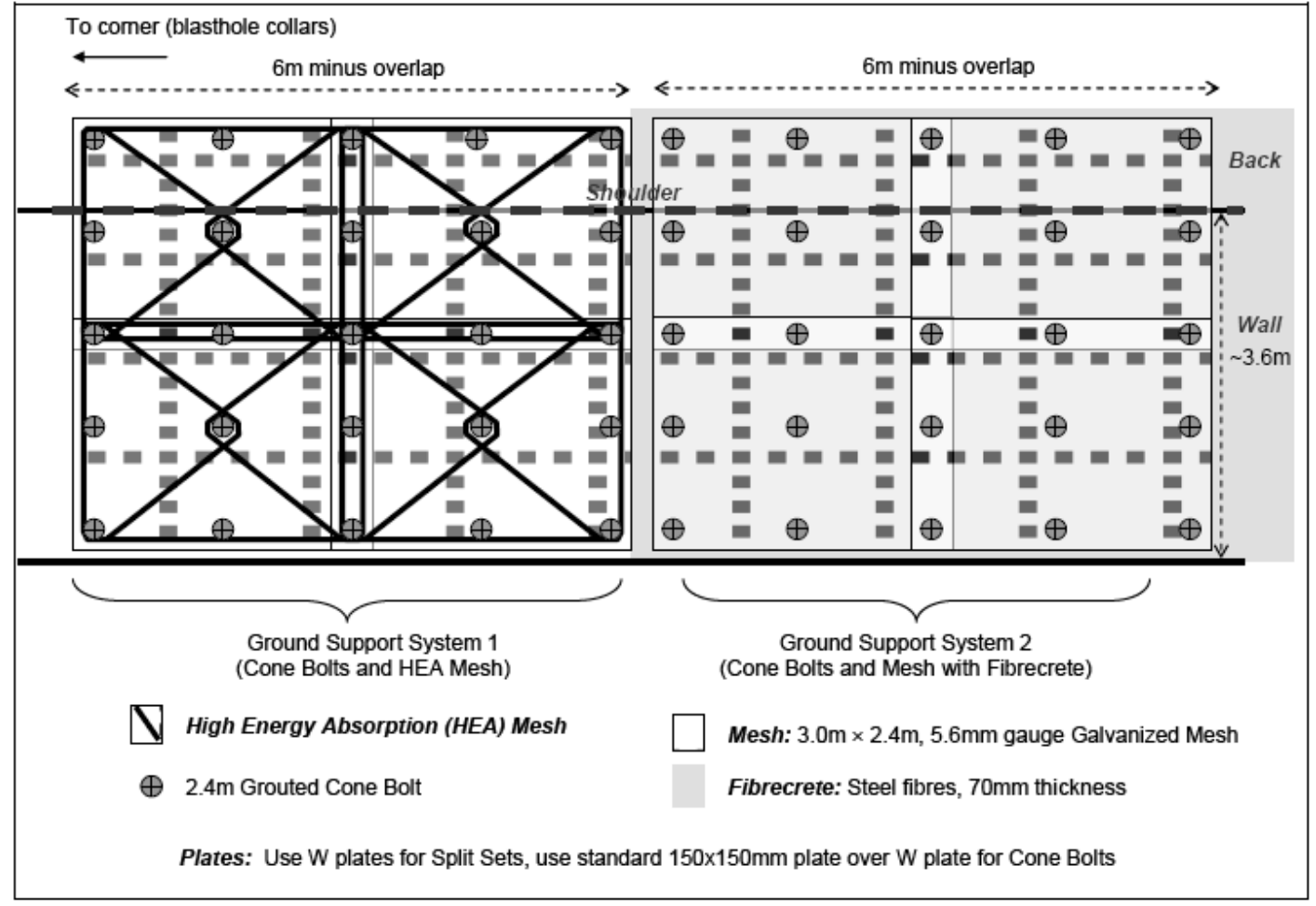

\section{Figure 6 Ground support layout instruction}

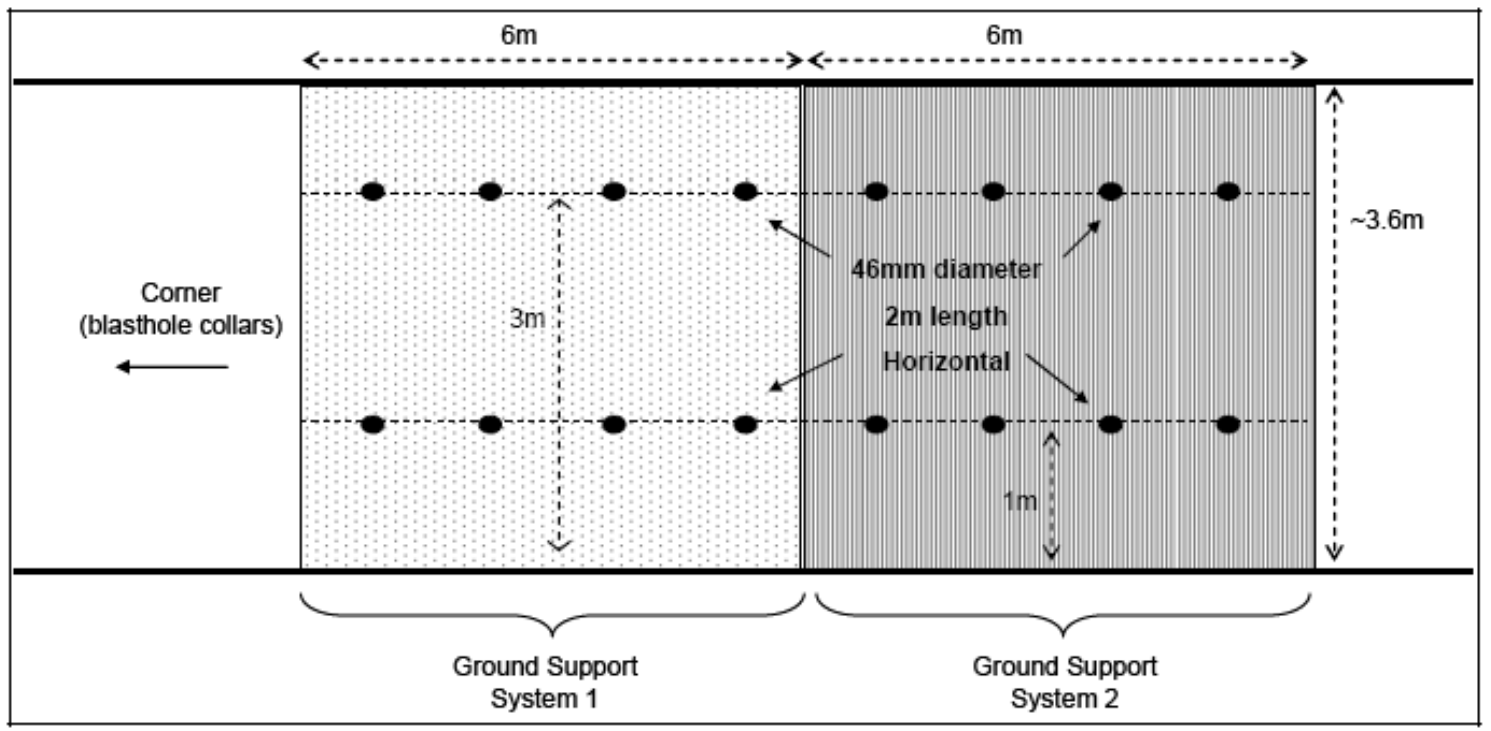

\section{Figure 7 Test wall drilling}

For this particular simulated rockburst test at Long Shaft, the blast design parameters are shown in Table 1. The blasthole drilling instructions issued prior to testing are shown in Figure 8. 
Table 1 Blast design parameters for simulated rockburst experiments at Long Shaft

\begin{tabular}{lcc}
\hline Product & Dyno Nobel Powermite Pro 80 $\times \mathbf{4 0 0}$ \\
Blast \# & $\mathbf{1}$ & $\mathbf{2}$ \\
\hline Hole position (m) & 3.5 & 3 \\
Hole length (m) & 13 & 13 \\
Charge length (m) & 5 & 6 \\
Uncharged (m) & 8 & 7 \\
\# cartridges & 12.5 & 15 \\
Mass (kg) & 26.00 & 31.20 \\
\hline & Maximum Expected PPV (m/s) \\
\hline CC $=0.79$ conservative & 1.2 & 1.6 \\
Upper percentile & 3.5 & 4.7 \\
CC $=1.0$ conservative & 1.4 & 1.9 \\
Upper percentile & 4.1 & 5.5 \\
\hline
\end{tabular}

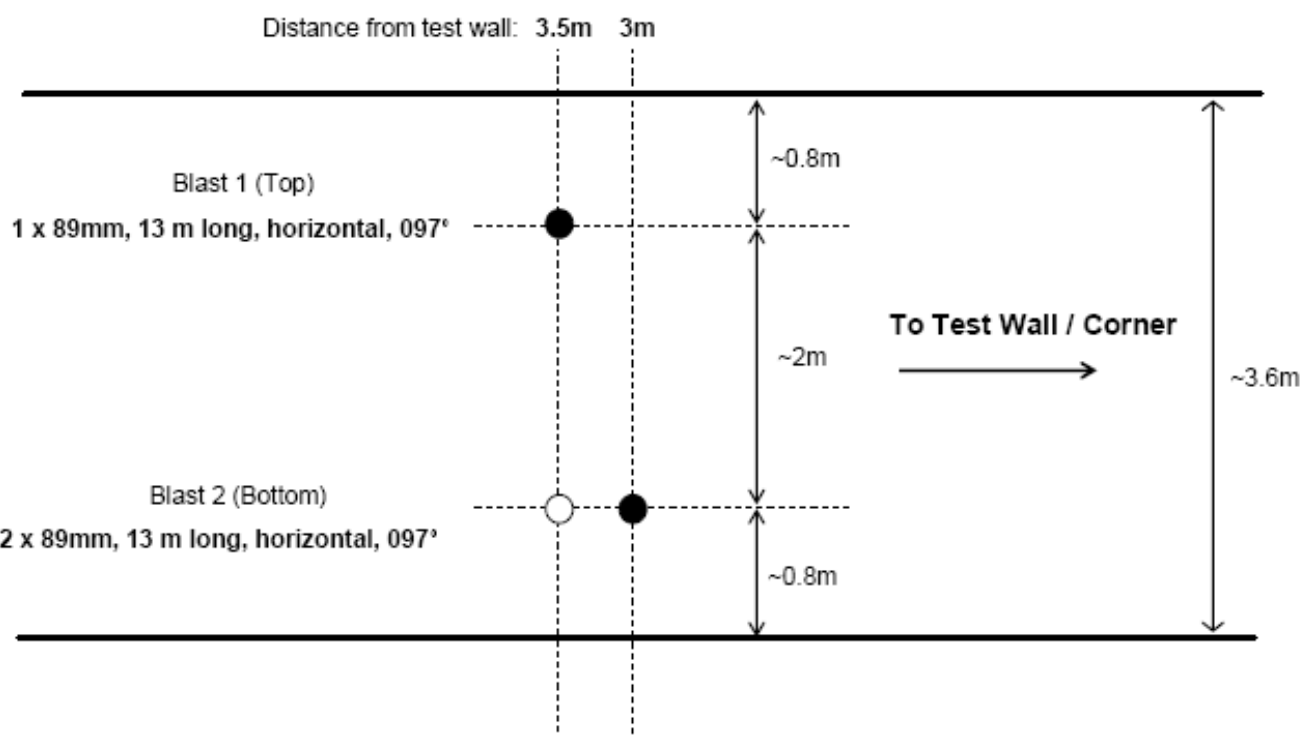

ALL HOLES DRILLED PARALLEL TO THE TEST WALL (AT A BEARING OF $097^{\circ}$ )

ALL HOLES DRILLED HORIZONTAL, AFTER INSTALLATION OF GROUND SUPPORT ON TEST WALL

Primary Blastholes

Spare Blasthole (may be required if primary blasthole is damaged during preceding blast)

\section{Figure 8 Blasthole drilling instruction}

Due to limitations in the availability of production drilling equipment at the mine at the time of testing, the blastholes provided for the tests were in fact $76 \mathrm{~mm}$ diameter as opposed to the design diameter of $89 \mathrm{~mm}$, resulting in the need to use $32 \times 200 \mathrm{~mm}$ cartridges of Powermite Pro in bundles of three. This resulted in using a slightly lower charge mass than designed. Nevertheless, peak particle velocities (PPV) achieved were adequate to generate a full range of damage on the test wall.

The maximum PPV recorded during Blast \#1 was $2.65 \mathrm{~m} / \mathrm{s}$, which is within the range of PPV estimates. Given the in-hole geometry of the charge used, it is likely that the uncoupled estimation was the most 
appropriate (coupling correction "CC" of 0.79). During Blast \#2 the maximum recorded (PPV) was $3.14 \mathrm{~m} / \mathrm{s}$, only marginally higher. It is likely that rapidly expanded gasses had some effect on the results in the centre of the test wall during Blast \#2. This explains the fact that PPVs achieved were somewhat lower than expected for the damage that resulted. Also, the waveforms for this blast seem to indicate a "heave" effect after the initial peak in ground motion. This is often an indicator of a gas effect. However, these issues did not necessarily affect the end result of the test as good data was obtained for the onset of loss of functionality of the ground support systems, which is the key index used to rate ground support systems using the simulated rockburst test method. The loss of functionality of the support system occurs at a lower energy demand than the values which were potentially affected by any gas effect.

\section{$4 \quad$ Monitoring and measurements}

Ground motion monitoring at each test site was conducted using heavily over-damped 14Hz SM6 geophones connected to a 16 channel Impulse seismic monitoring system. Inclusion of a damping resistor in each geophone circuit allowed a much higher velocity to be recorded (up to around $5 \mathrm{~m} / \mathrm{s}$ ). The impulse system allows a maximum sampling rate of $10 \mathrm{kHz}$ per channel, which is adequate to prevent aliasing of waveforms, considering the maximum frequency of ground motion expected to be generated by blasting is not more than $1 \mathrm{kHz}$. Surface mounted geophones are used to measure the ground velocity generated by blasting. Geophone locations are shown in Figure 9.

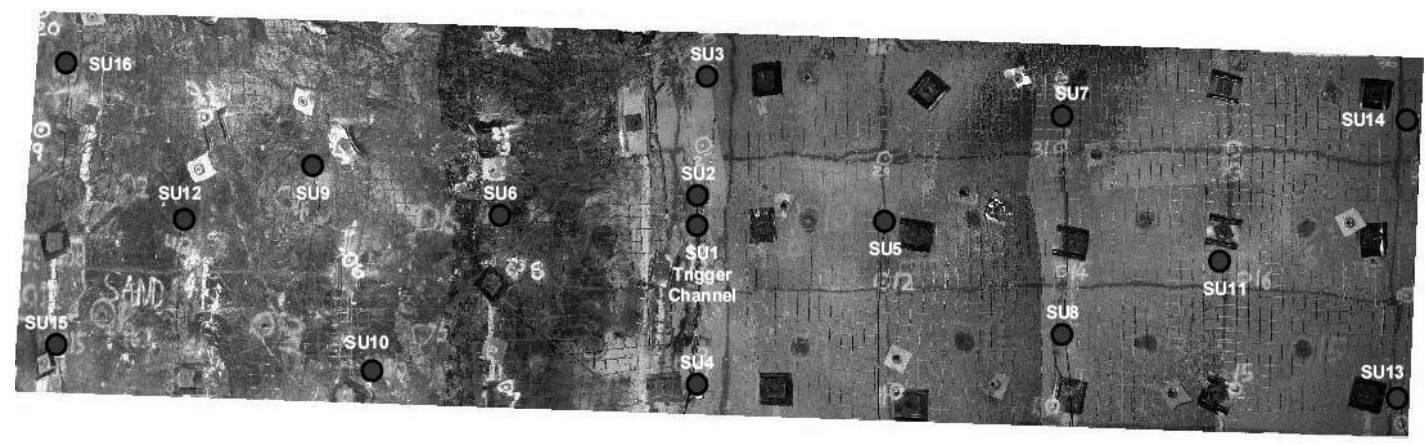

\section{Figure 9 Test wall geophone locations}

The $46 \mathrm{~mm}$ observation holes (Figure 7) were used to assess the depth and nature of rock mass fracturing before and after each blast and, specifically, the thickness of failed rock acting upon the ground support for use in energy demand calculations.

Extensive mapping of each test site before and after each blast was carried out using Sirovision ${ }^{\circledR}$ (http://www.sirovision.com/), a three-dimensional photogrammetry system developed by the CSIRO and designed primarily for structural mapping of underground or open pit rock faces. Sirovision ${ }^{\circledR}$ allows the generation of fully digitised three dimensional images from stereo pairs of photographs, when accurate survey support is available. As well as mapping, images generated before and after successive blasts were used to identify areas of rock bulking or ejection, accurately measure deformation of surface support and measure the displacement of rockbolt plates and ends. These measurements contributed to the qualitative and quantitative assessment of ground support system performance.

The two simulated rockbursts were recorded using a Canon MV960 digital video camera. The camera is used to maintain a permanent record of each simulated rockburst, as well as assessment of the behaviour of ejected rock and support fragments during the experiments.

Throughout the simulated rockburst testing, the support damage scale (SDS) (Kaiser et al., 1992) has been used to assess damage to each ground support system (see Table 2). The SDS allows comparison of damage between the support systems tested, to which measured PPVs or energy demands can be matched. 
Table 2 SDS used in the simulated rockburst experiments

\begin{tabular}{|c|c|c|c|}
\hline $\begin{array}{l}\text { Damage } \\
\text { Level }\end{array}$ & General Description & Support Damage & Shotcrete Damage \\
\hline S0 & Conditions unchanged. & No new damage or loading. & No new damage or loading. \\
\hline S1 & $\begin{array}{l}\text { Support undamaged but } \\
\text { first signs of distress } \\
\text { detectable. }\end{array}$ & $\begin{array}{l}\text { No damage to any support } \\
\text { component. }\end{array}$ & $\begin{array}{l}\text { Shotcrete shows new cracks, } \\
\text { very fine or widely } \\
\text { distributed. }\end{array}$ \\
\hline \multirow[t]{2}{*}{ S2 } & $\begin{array}{l}\text { Slight damage to } \\
\text { support. }\end{array}$ & $\begin{array}{l}\text { Plates and wooden washers on some } \\
\text { rockbolts are deformed, showing } \\
\text { loading. }\end{array}$ & $\begin{array}{l}\text { Shotcrete cracked, minor } \\
\text { flakes dislodged. }\end{array}$ \\
\hline & $\begin{array}{l}\text { but full functionality } \\
\text { maintained. }\end{array}$ & $\begin{array}{l}\text { Individual strands in mesh broken. } \\
\text { Mesh bagged but retains material }\end{array}$ & $\begin{array}{l}\text { load from broken rock mass } \\
\text { (mostly drummy). }\end{array}$ \\
\hline
\end{tabular}

S3 Moderate damage to support.

Support shows significant loading and local loss of functionality; retaining function primarily lost (except in laced or shotcreted areas). well.

Plates, wooden washers, and wood blocking on rockbolts are heavily deformed, showing significant loading; bolt heads may be "sucked" into rock.

Mesh torn near bolt heads with some strands broken and mesh torn or opened at overlapping edges.

Moderate bagging of mesh and isolated failures of rockbolts.

Cable lacing performs well.

S4 Substantial damage to support.

More extensive loss of retaining and holding functions (except for lacing systems).

\section{Mesh is often torn and pulled over} rockbolt plates; if it did not fail, it is substantially bagged (at capacity).

Many rockbolts failed.

Rock ejected between support components.

Cable lacing is heavily loaded with bagged mesh.

S5 Severe damage to support.

Most ground support components broken or damaged.

Support retaining, holding, and reinforcing functions failed.

Most rockbolts fail and rock peels off cable bolts.

Shotcrete fractured, often debonded from rock and/or reinforcement.

Major flakes possibly dislodged.

Holding elements mostly intact.

Shotcrete heavily fractured and broken, often separated from the rock mass with pieces lying on the ground or hanging from reinforcement. (Connections to holding elements often failed or holding elements failed locally).

For damage level S5, shotcrete fails to be functional and the left-hand column applies.

Shotcrete non-functional.

Mesh without cable lacing heavily torn and damaged.

Cable lacing systems heavily stressed and often failed.

\footnotetext{
Notes: 1) The damage indicators listed in this table describe damage that is new and was caused by the rockburst. If the observer cannot ascertain that the damage was inflicted by the rockburst then the damage should be ignored for the purposes of damage classification.

2) One or more damage scales may be observed in same section and should be recorded separately.

3) Rock and support damage levels need not correspond.

4) Because the function of shotcrete support is somewhat different and more complex than for other support systems, a separate column of indicators is provided over the range of SO to S4. It is important to record where shotcrete is present and when it has been used to determine the support damage level.

5) Failure of rockbolt applies to failure of nut, plate, anchor or shank.

6) From: Kaiser, P.K., Tannant, D.D., McCreath, D.R. and Jesenak, P. (1992) 'Rockburst damage assessment procedure', Rock Support in Mining and Underground Construction, P.K. Kaiser and D.R. McCreath (eds), Balkema, Rotterdam, pp. 639-647.
} 


\section{$5 \quad$ Results}

\section{1 $\quad$ First blast}

The first blast resulted in minor damage to the cone bolts and HEA Mesh support system, with the ejection or shaking out of some small fragments between the mesh apertures, whilst the fibrecrete side suffered localised minor cracking. Although PPVs generated by the blast were quite high (up to $2.4 \mathrm{~m} / \mathrm{s}$ ), the lack of a significant failure thickness meant the energy demand on the ground support was low. The borehole camera survey following the blast showed that there was significant rock mass fracturing brought about by the blast. A detailed damage description is given in Table 3.

Table 3 First blast ground support system performance summary

\begin{tabular}{lll}
\hline $\begin{array}{l}\text { Ground } \\
\text { Support System }\end{array}$ & $\begin{array}{l}\text { Range of PPVs } \\
\text { Measured on } \\
\text { Test Wall }\end{array}$ & Description of Damage \\
\hline $\begin{array}{l}\text { 1) Cone bolts and } \\
\text { HEA Mesh }\end{array}$ & $0.3-2.4 \mathrm{~m} / \mathrm{s}$ & $\begin{array}{l}\text { Conditions unchanged to slight damage to support (S0 to S2). } \\
\text { Worst damage suffered in central area of test wall where PPV's } \\
\text { were highest. Damage ranged from the first signs of distress, with } \\
\text { some broken rock material contained behind mesh, to minor rock } \\
\text { mass bulking and bagging of the mesh. Cone bolt plates slightly } \\
\text { deformed in areas of worst damage, but rockbolts otherwise } \\
\text { undamaged. Minor ejection of rock fragments between individual } \\
\text { mesh apertures. Ground support system 1 contained the simulated } \\
\text { rockburst damage generated by this first blast. }\end{array}$ \\
$\begin{array}{l}\text { 2) Cone bolts and } \\
\text { mesh with }\end{array}$ & $0.3-2.2 \mathrm{~m} / \mathrm{s}$ & $\begin{array}{l}\text { Conditions unchanged to first signs of distress (S0 to S2). } \\
\text { Minor cracking of fibrecrete in central area of test wall, } \\
\text { fibrecrete }\end{array}$ \\
& & $\begin{array}{l}\text { coincident with area of highest PPV. Support system contained } \\
\text { the simulated rockburst well and also prevented ejection of small } \\
\text { scats. }\end{array}$ \\
\hline
\end{tabular}

\subsection{Second blast}

The second blast resulted in very heavy damage to the central section of the test wall, incorporating both support systems. In total approximately 100 tons of material were ejected from the test wall. PPVs generated were affected by the location of the test wall relative to the second blasthole. The blasthole was somewhat closer to the test wall than designed, and the mid-length point of the hole was closer to the HEA Mesh and cone bolts side, resulting in a concentration of high PPVs and damage on that side (Figure 11). Whilst the highest PPVs generated by this blast were comparable to the first, the significant failure thickness created by the first blast allowed for very high energy demands during the second blast. There were likely some gas effects on the test wall in the second blast, however, these do not appear to have influenced the results, which are dependent on the onset of damage (SDS $=\mathrm{S} 3$ ) to determine support system performance. A more detailed description of test wall damage is shown in Table 4. 
Table 4 Second blast ground support system performance summary

\begin{tabular}{|c|c|c|}
\hline $\begin{array}{l}\text { Ground } \\
\text { Support System }\end{array}$ & $\begin{array}{l}\text { Range of PPVs } \\
\text { Measured on } \\
\text { Test Wall }\end{array}$ & Description of Damage \\
\hline \multirow{2}{*}{$\begin{array}{l}\text { 1) Cone bolts and } \\
\text { HEA Mesh }\end{array}$} & \multirow[t]{2}{*}{$0.8-3.0 \mathrm{~m} / \mathrm{s}$} & First signs of distress to severe damage to support ( $\mathrm{S} 1$ to $\mathrm{S} 5$ ). \\
\hline & & $\begin{array}{l}\text { The condition of the test wall after the blast ranged from little or } \\
\text { no damage on the far left, to complete failure and ejection on the } \\
\text { right. Some areas of the wall showed significant deformation (up } \\
\text { to around } 0.3 \mathrm{~m} \text { ) which was contained by the ground support. } \\
\text { This would suggest some cone bolts yielded. Other cone bolts } \\
\text { were found to be completely ejected suggesting grout strength } \\
\text { may have been too low. The HEA mesh lacing was generally still } \\
\text { in-tact, despite being significantly bent and forced away from the } \\
\text { test wall. }\end{array}$ \\
\hline \multirow{2}{*}{$\begin{array}{l}\text { 2) Cone bolts and } \\
\text { mesh with } \\
\text { fibrecrete }\end{array}$} & \multirow[t]{2}{*}{$0.6-1.9 \mathrm{~m} / \mathrm{s}$} & First signs of distress to severe damage to support (S1 to S5). \\
\hline & & $\begin{array}{l}\text { A short section of this ground support near the centre of the test } \\
\text { wall was completely ejected. Damage then ranged down the full } \\
\text { spectrum of the SDS, with severe bulking and cracking of } \\
\text { fibrecrete near the centre to minor cracking to the right. }\end{array}$ \\
\hline
\end{tabular}

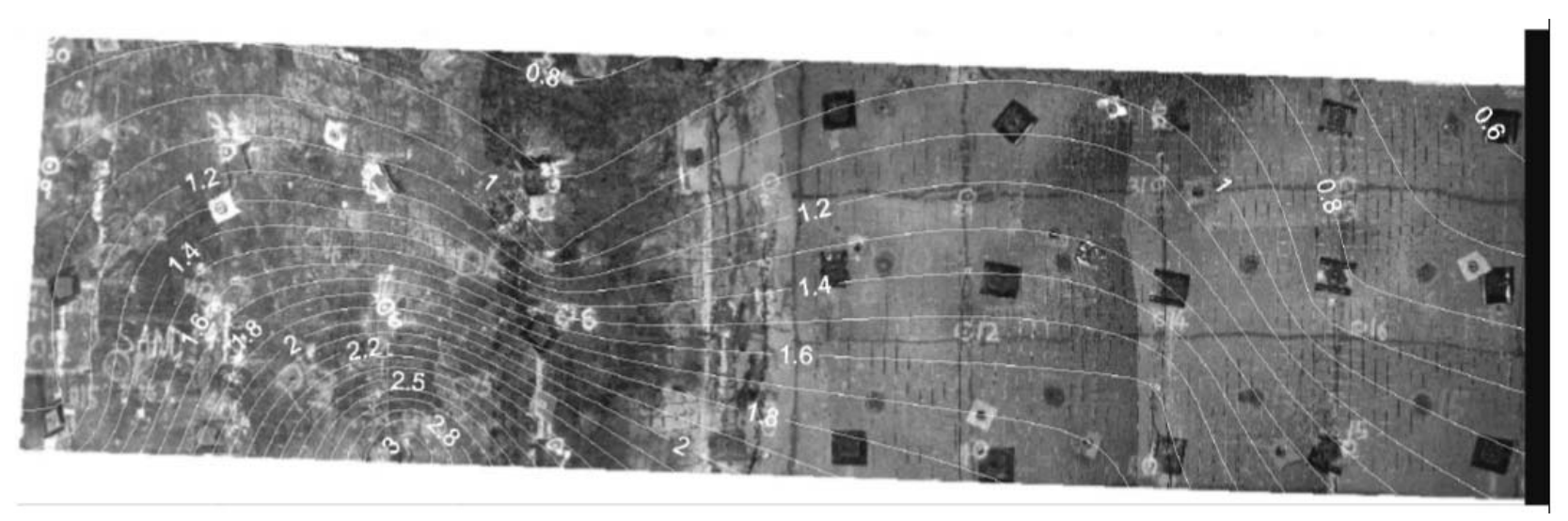

Figure 11 Second blast PPV contour

The severe damage generated by the second simulated rockburst is shown in Figure 12. The level of damage was likely influenced by the geometry of the charge relative to the test wall, with the blasthole closer to the test wall than designed, particularly in the HEA Mesh and cone bolts section. Selected photographs of the damage to the test wall due to the second blast are shown in Appendix A. These photos show that many of the cone bolts appear to have been pulled out, with evidence of cone bolt plough such as striations lengthwise along the bolts. It is conceivable that the grout may have been too weak in this case and once the HEA Mesh was loaded, the lacing pulled many of the cone bolts out as the entire system deformed. 


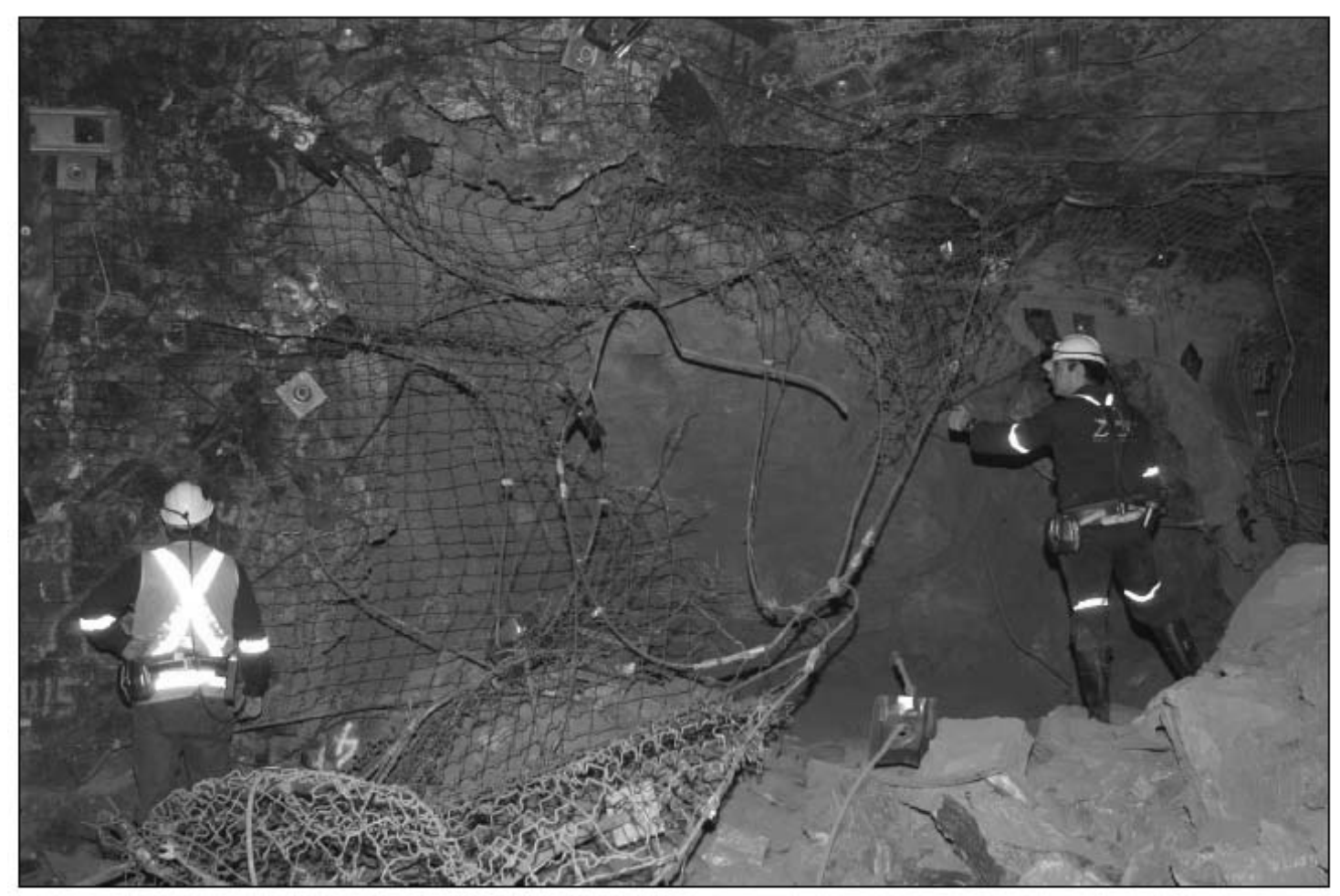

Figure 12 Test wall after the second blast

\section{Analysis}

A damage assessment for the simulated rockburst was carried out by separating the test wall into grid squares. Each grid square represents a data point, for which there exists a PPV taken from contour plots of test wall PPV, a failure thickness as measured using the borehole camera and a support damage SDS rating. Measurement of failure thickness allows calculation of the energy demand $\left(\mathrm{kJ} / \mathrm{m}^{2}\right)$ over the test wall, which accounts for not only the PPV generated during each simulated rockburst but also the mass of failed rock acting on the ground support system. Energy demand from the wall motion is calculated using the equation:

$$
\text { Energy demand per square metre }=\frac{1}{2} \mathrm{t} \rho \mathrm{v}^{2}
$$

where:

$\mathrm{t}=$ the failure thickness $(\mathrm{m})$ of rock acting upon the support system at each grid point.

$\rho \quad=\quad$ the rock density $\left(\mathrm{kg} / \mathrm{m}^{2}\right)$ at the grid point.

$\mathrm{v}=$ the peak particle velocity at the grid point as measured by the surface mounted geophones and contoured on the test wall.

The damage assessment procedure is shown graphically in Figure 13. There are many site specific factors which probably influence the damage generated by the simulated rockburst, such as local stress conditions, rock type, rock mass discontinuities and blast related damage. It is considered that all of these factors contribute to the two variables used to analyse the data - failure thickness and PPV. The analysis technique is simplified by considering only the result of these influences, rather than attempting to quantify each influence individually. 


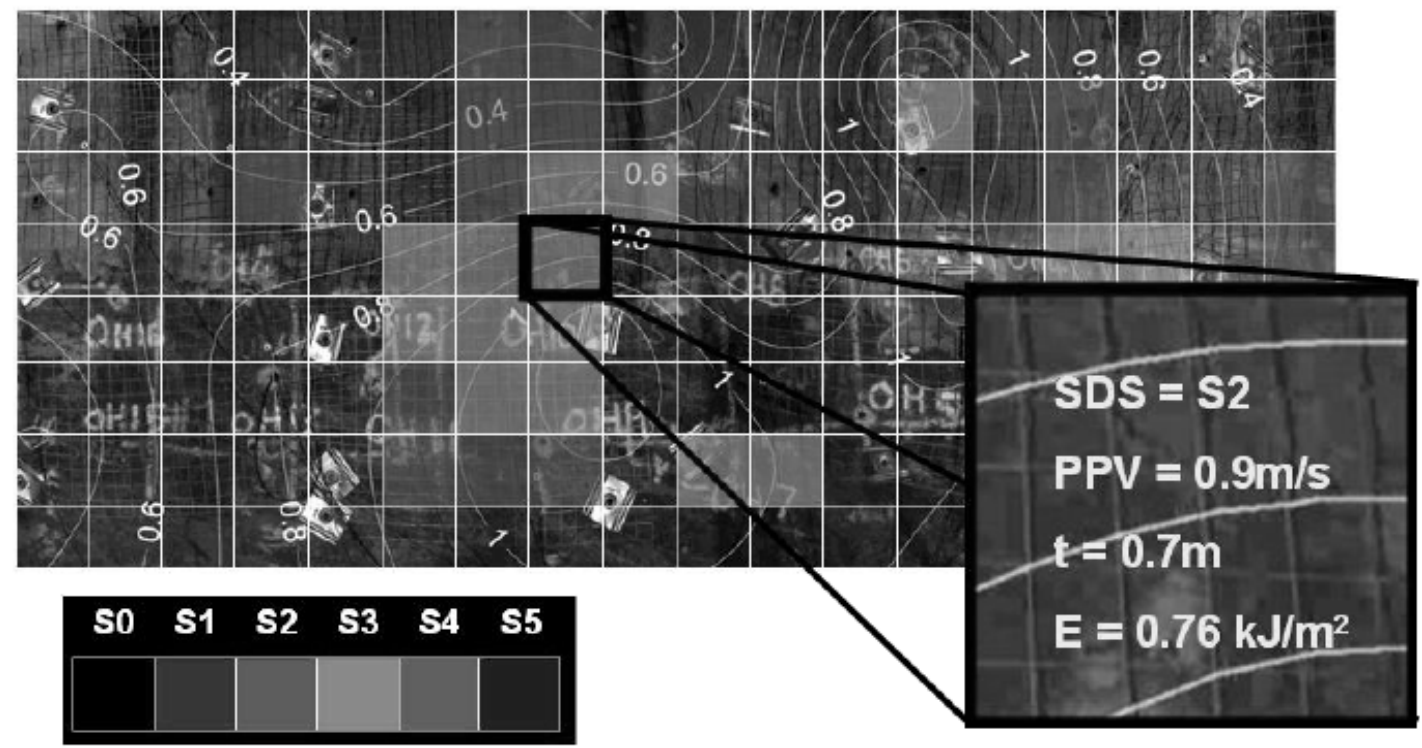

Figure 13 An example of the damage assessment procedure - each grid square is assigned a SDS rating, a PPV and a failure thickness to give a value for energy demand per square metre

The results of the damage assessment are shown in Tables 5 and 6 and Figures 14 and 16. As shown in Figure 14, support damage scale level S3 occurred at an average of around $9 \mathrm{~kJ} / \mathrm{m}^{2}$ energy demand for the cone bolts and HEA Mesh support system.

Table 5 Cone bolts and HEA Mesh support performance

\begin{tabular}{|c|c|c|c|c|c|c|}
\hline \multicolumn{7}{|c|}{1 - Cone Bolts and HEA Mesh } \\
\hline & SDS & S1 & S2 & S3 & S4 & S5 \\
\hline \multirow{4}{*}{ 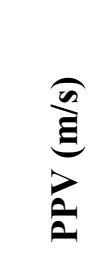 } & Min & 0.90 & 0.90 & 1.00 & 1.00 & 0.80 \\
\hline & $\operatorname{Max}$ & 2.40 & 2.10 & 2.30 & 2.70 & 3.00 \\
\hline & Ave & 1.43 & 1.46 & 1.61 & 1.76 & 1.57 \\
\hline & Median & 1.30 & 1.40 & 1.60 & 1.70 & 1.30 \\
\hline \multirow{4}{*}{ 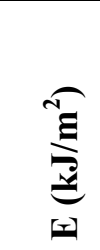 } & Min & 1.07 & 1.56 & 2.96 & 2.96 & 1.89 \\
\hline & $\operatorname{Max}$ & 6.82 & 10.06 & 18.01 & 26.97 & 33.30 \\
\hline & Ave & 2.83 & 4.30 & 8.96 & 12.00 & 9.96 \\
\hline & Median & 2.32 & 3.77 & 7.58 & 9.41 & 5.50 \\
\hline
\end{tabular}




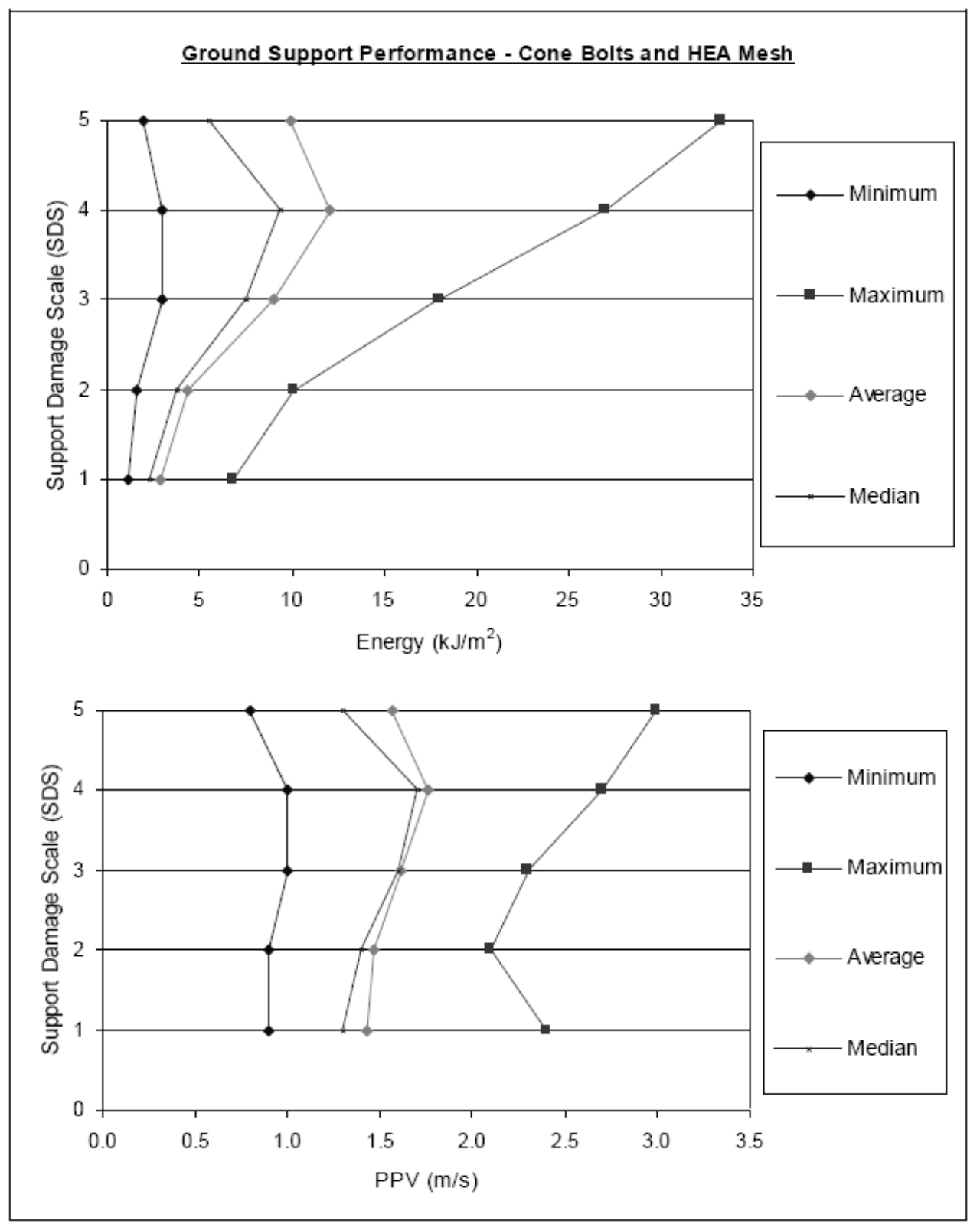

Figure 14 Cone bolts and HEA Mesh support performance

This damage level is significant because it is the level at which the loss of support functionality occurs, significant rock ejection is possible and rehabilitation would be required.

In general, there is a slightly increasing PPV for the damage levels encountered, but there is a much stronger relationship between energy demand and ground support system performance. Energy demands at lower damage levels (S1, S2) appear comparable to other ground support systems tested, however, once higher energy demands are achieved, the HEA Mesh and cone bolts system rapidly gains capacity. This is likely due to the fact that the cable lacing built into the HEA Mesh is not engaged until significant support system deformation is achieved.

Despite the extremely high energy demands which were achieved in this test (up to around $35 \mathrm{~kJ} / \mathrm{m}^{2}$ ), the lacing component of the HEA Mesh remained intact. No breaks in the lacing were observed, despite it being heavily bent and deformed. This indicates that the HEA Mesh shows good potential for providing high energy capacity in a rockburst prone environment when a suitably strong and yielding reinforcing element is used. Many of the cone bolts were pulled out of the grout demonstrating a very efficient transfer of force between the surface support and the reinforcement. 


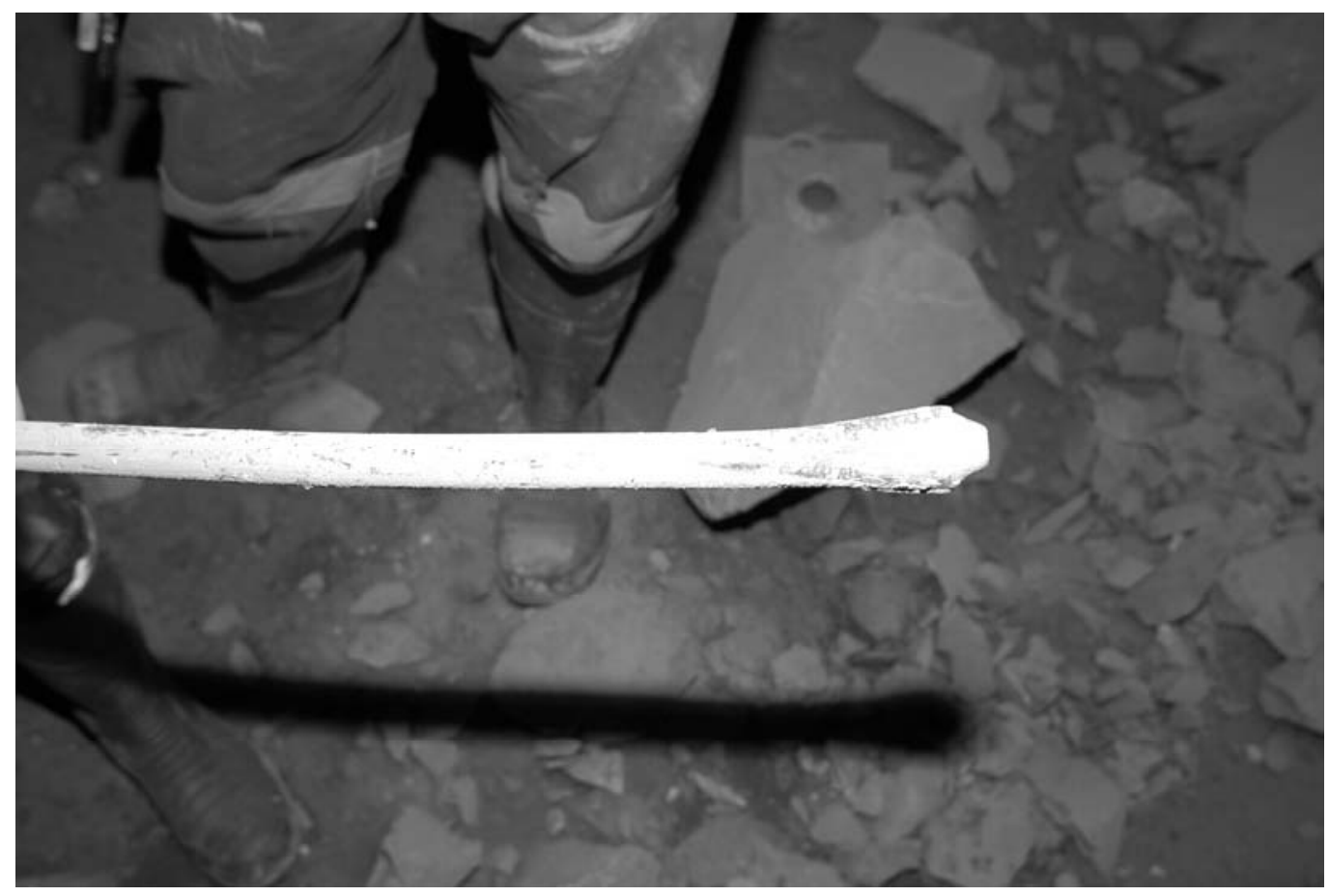

Figure 15 Cone bolts pulled out of the grout during the second blast

The test showed, however, that the HEA Mesh is susceptible to the quality of installation. Areas where the ground support system was most heavily damaged coincided with where the lacing was not tight around the cone bolts and a good overlap was not achieved. This may be attributable to the manual installation of the HEA Mesh.

The performance of cone bolts and mesh with fibrecrete, in terms of energy absorption, was approximately $45 \%$ lower than the HEA Mesh support system. In this case, S3 damage occurred at an average of approximately $5 \mathrm{~kJ} / \mathrm{m}^{2}$ (Table 6 and Figure 16). This is an almost identical result to other support systems tested using the simulated rockburst method with mesh (with or without fibrecrete) and rockbolts at a spacing of around 1.2-1.5 m (Figure 17). The stiff fibrecrete and mesh surface support generally provides adequate load transfer to individual rockbolts only at energy demands of around $5 \mathrm{~kJ} / \mathrm{m}^{2}$ or less. The damage to this section of the test wall showed a very sharp transition from severe damage to minor damage. This is more a function of the rapid attenuation of PPVs further from the worst affected section of the test wall (as shown in Figure 11) rather than a property of the support system.

Table 6 Cone bolts and mesh with fibrecrete support performance

\begin{tabular}{|c|c|c|c|c|c|c|}
\hline \multicolumn{7}{|c|}{2 - Cone bolts and Mesh with Fibrecrete } \\
\hline & SDS & S1 & S2 & S3 & S4 & S5 \\
\hline \multirow{4}{*}{ 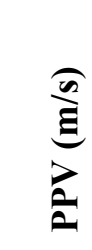 } & Min & 0.60 & 1.00 & 1.00 & 1.10 & 1.20 \\
\hline & Max & 2.20 & 1.50 & 1.70 & 1.70 & 3.20 \\
\hline & Ave & 1.02 & 1.13 & 1.37 & 1.38 & 2.49 \\
\hline & Median & 0.90 & 1.10 & 1.40 & 1.35 & 2.95 \\
\hline \multirow{4}{*}{ 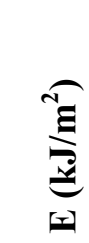 } & Min & 0.21 & 2.81 & 2.96 & 3.58 & 4.48 \\
\hline & Max & 5.01 & 5.66 & 8.13 & 9.41 & 25.20 \\
\hline & Ave & 2.09 & 3.59 & 5.40 & 5.82 & 14.08 \\
\hline & Median & 1.90 & 3.40 & 5.00 & 5.40 & 12.75 \\
\hline
\end{tabular}




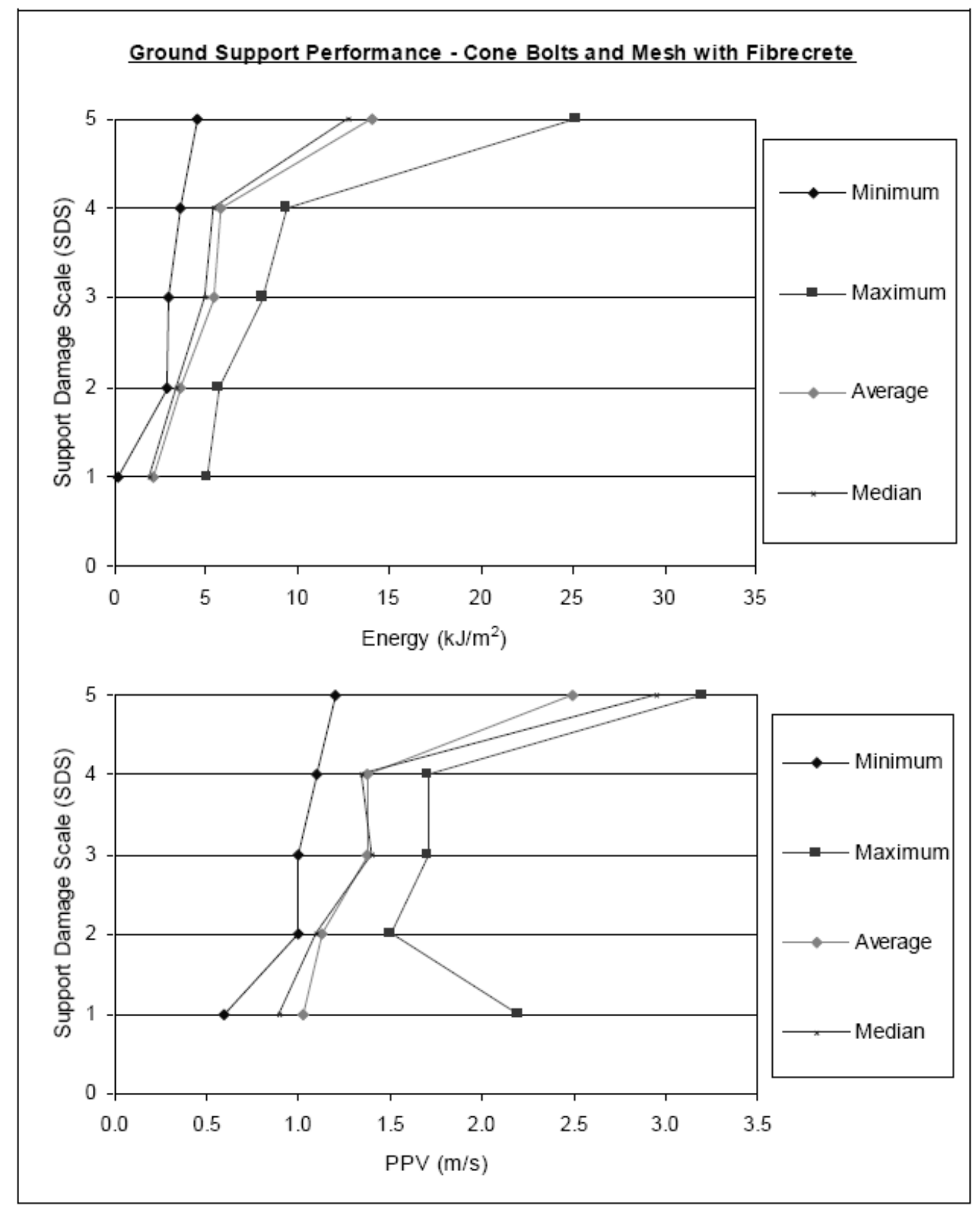

Figure 16 Cone bolts and mesh with fibrecrete support performance

\section{Discussion}

Figure 17 shows a comparison of ground support systems tested using simulated rockbursts from a number of mine sites, as well as some data from actual rockburst case histories from the ACG rockburst catalogue (Heal et al., 2006; Heal, 2010). The chart shows the average energy demand for S3 damage. The PPV for the actual rockburst data blue line in Figure 17) was estimated using a far-field scaling law. All ground support systems using only one type of bolt (e.g. split sets and mesh, securabolts and fibrecrete, etc.) had a bolt spacing of $1.2 \times 1.5 \mathrm{~m}$. The systems using two types of bolt systems tested generally had a bolt spacing of around half that. 


\section{Comparison of Ground Support Systems}

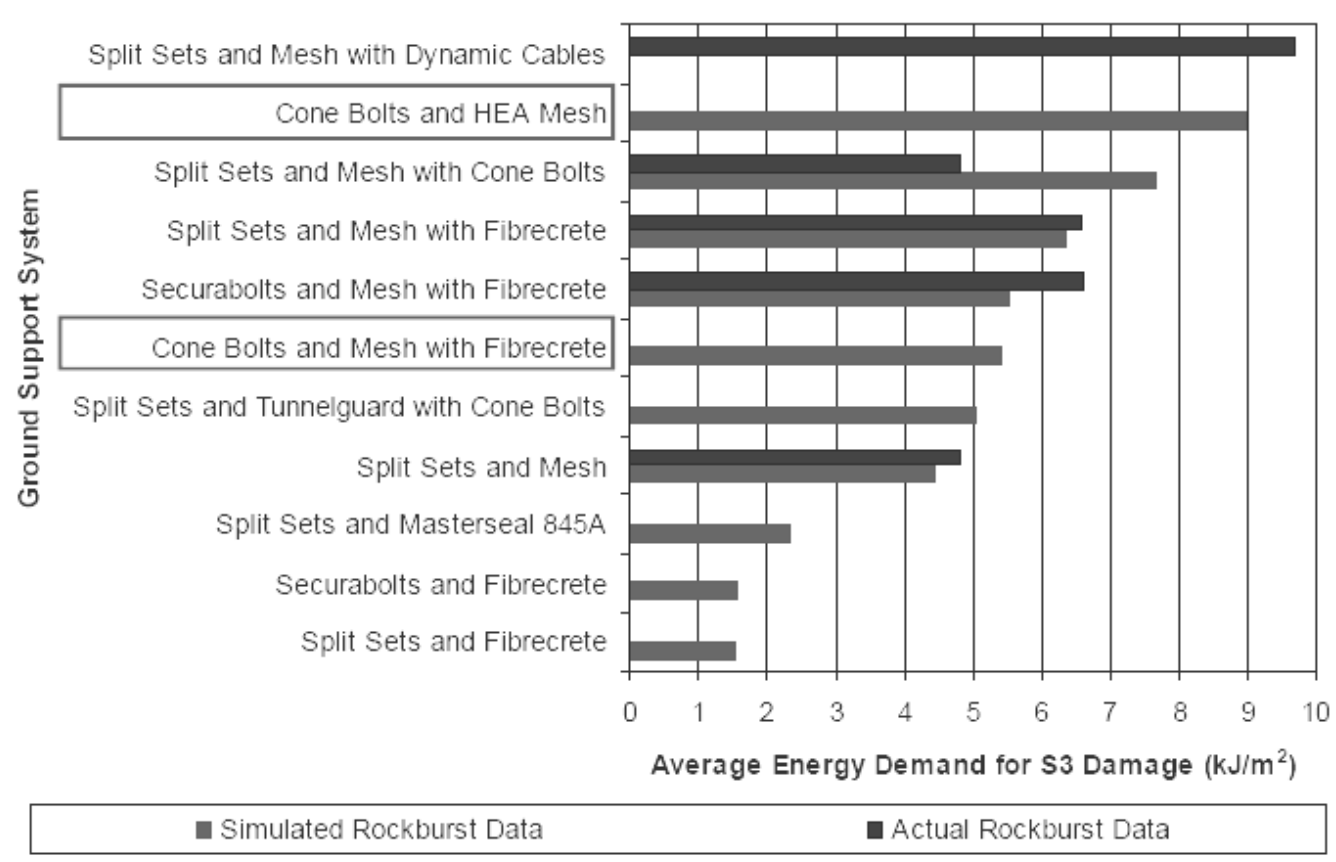

Figure 17 Comparison of ground support performance (after Heal, 2010)

Figure 17 demonstrates the consistently better performance of support systems incorporating strong and ductile surface support over those which do not. In the test described in this paper, the same rock bolt was tested on both sides of the test wall, however, the surface support varied. The HEA Mesh was shown to almost double the overall capacity of the ground support system. A finding of previous simulated rockburst testing was that the overall performance of a ground support system in dynamic loading is strongly controlled by:

- the spacing of the rock reinforcing elements (rockbolts or cables)

- the strength and ability of the surface support to transfer the dynamic load to the individual rock bolt elements.

The chart shows that ground support systems without mesh can be expected to fail at energy demands of around $1.5-2 \mathrm{~kJ} / \mathrm{m}^{2}$ while those with mesh can be expected to fail at energy demands of around $5-8 \mathrm{~kJ} / \mathrm{m}^{2}$, depending on overall bolt spacing. The exception is the split sets and tunnelguard with cone bolts system. In that case, it was thought that the tighter bolt spacing meant there was better load transfer to the individual rockbolt units, which prevented some of the damage that would have otherwise occurred to the tunnelguard.

The addition of cable lacing to the HEA Mesh markedly improved the dynamic capacity of the system at higher damage levels. It appears that the cable lacing is not engaged until significant deformation has already occurred during dynamic loading. As such, the lacing can be thought of as the last line of defence against material ejection during dynamic loading as significant damage would have already occurred to the mesh and/or rockbolts by the time it is fully engaged.

The benefit of a fibrecrete system is that, under medium energy demand (up to $5 \mathrm{~kJ} / \mathrm{m}^{2}$ ), fibrecrete and mesh surface support systems result in good load transfer to individual rockbolt units as they are sufficiently strong and stiff. However, with a high quality installation and the right choice of rock bolt, the HEA Mesh is likely to demonstrate very high energy capacity in an actual rockburst.

\section{Acknowledgements}

The ACG sincerely thanks the personnel at the Long Shaft Mine whose work contributed to the testing, particularly Dave O'Toole and Peter Mikula. OneSteel Reinforcing is also acknowledged for their 
involvement in the manufacture and supply of the HEA Mesh. Funding for this research was provided through the Mine Seismicity and Rockburst Risk Management project at the Australian Centre for Geomechanics. This project is financially supported by:

- Agnico-Eagle Mines Ltd

- AngloGold Ashanti Australia

- Barrick Gold of Australia

- BCD Resources (Operations) NL (previously Allstate Exploration Beaconsfield Gold NL)

- BHP Billiton Nickel West

- Codelco Chile (E1 Teniente)

- Gold Fields Australia (St Ives and Agnew Gold)

- Harmony Mt Magnet Gold

- Kalgoorlie Consolidated Gold Mines

- Kirkland Lake Gold

- Lightning Nickel (Independence Group NL)

- Luossavaara-Kiirunavaara Aktiebolag (LKAB)

- Minerals and Energy Research Institute of Western Australia (MERIWA)

- MMG Minmetals Group (Golden Grove) (previously Oxiana Limited and Oz Minerals)

- Newcrest Cadia Valley Operations (Ridgeway)

- Newmont Asia Pacific

- Norilsk Nickel (formerly LionOre Australia Ltd)

- Perilya Limited

- Reliance Nickel P/L (Consolidated Minerals Group)

- Xstrata Copper (Kidd Mine)

- Xstrata Zinc (Brunswick Mining and Smelting)

- Xstrata Nickel (Cosmos Nickel Project) (previously Sir Samuel Mines).

\section{References}

Heal, D. (2010) Observations and analysis of incidences of rockburst damage in underground mines, PhD Thesis (submitted June 2010), The University of Western Australia, Perth.

Heal, D. and Potvin, Y. (2007) In-situ dynamic testing of ground support using simulated rockbursts, in Proceedings Fourth International Seminar on Deep and High Stress Mining (Deep Mining07), Y. Potvin (ed), 7-9 November 2007, Perth, Australia, Australian Centre for Geomechanics, Perth, pp. 373-394.

Heal, D., Potvin, Y. and Hudyma, M. (2006) Evaluating rockburst damage potential in underground mining, in Proceedings of the American Rock Mechanics Association (ARMA) 41st U.S. Rock Mechanics Symposium (USRMS): 50 Years of Rock Mechanics — Landmarks and Future Challenges, Golden, Colorado, Canada, June, Paper no. 1020, CD format only, $12 \mathrm{p}$.

Kaiser, P.K., Tannant, D.D., McCreath, D.R. and Jesenak, P. (1992) Rockburst damage assessment procedure, Rock Support in Mining and Underground Construction, P.K. Kaiser and D.R. McCreath (eds), Balkema, Rotterdam, pp. 639-647.

Ortlepp, W.D. and Stacey, T.R. (1997) Testing of tunnel support: dynamic load testing of rock support containment systems, SIMRAC GAP Project 221.

Potvin, Y. (2009) Surface support in extreme ground conditions - HEA Mesh, in Proceedings First International Seminar on Safe and Rapid Development Mining (SRDM), P. Dight (ed), 6-7 May 2009, Perth, Australia, Australian Centre for Geomechanics, Perth, pp. 111-119. 
Potvin, Y. and Giles, G. (2008) The development of a new high energy absorption mesh, in Proceedings Tenth Underground Operators' Conference - 'Boom and Beyond', Tasmania, AUSIMM Publication Series 2/2008, 14-16 April 2008, Launceston, Australia, pp. 89-94. 